\title{
Pemodelan Faktor-Faktor yang Memengaruhi Persentase Peserta Aktif KB Suntik di Jawa Timur Menggunakan Regresi Nonparametrik Spline Truncated
}

\author{
Octavianta Romauli Sitanggang, Madu Ratna, dan I Nyoman Budiantara \\ Departemen Statistika, Fakultas Matematika, Komputasi, dan Sains Data, \\ Institut Teknologi Sepuluh Nopember (ITS) \\ e-mail: i_nyoman_b@statistika.its.ac.id
}

\begin{abstract}
Abstrak-Penggunaan metode kontrasepsi suntik di Jawa Timur pada akhir tahun 2015 mencapai angka 58,7\%. Metode kontrasepsi suntik sering dipakai karena tingkat efektifitasnya yang tinggi. Maka dari itu dilakukan penelitian untuk mengetahui faktor-faktor apa yang mempengaruhi presentasepeserta KB aktif di Provinsi Jawa Timur tahun 2016 memilih memakai metode kontrasepsi suntik. Penelitian ini menggunakan analisis regresi nonparametrik spline truncated karena sifatnya yang fleksibel untuk memodelkan data yang tidak memiliki pola. Data yang digunakan dalam penelitian ini adalah persentase peserta KB aktif dari alat KB suntik pada tahun 2016 di Jawa Timur sebagai variabel respon dan variable prediktor yang diduga memengaruhi adalah persentase perempuan berstatus kawin usia 15-49 tahun, jumlah anak lahir hidup dari setiap wanita usia 15-49 tahun lebih dari atau sama dengan 2 , tingkat pendidikan dari setiap wanita usia 15-49 tahun minimal SLTA/sederajat dan usia kawin pertama lebih dari 19 tahun. Hasil dari penelitian ini adalah model terbaik yang didapatkan dari memilih titik knot optimum adalah regresi nonparametrik spline truncated dengan kombinasi knot (1-3-3-3). Keempat variabel prediktor dugaan, berpengaruh signifikan terhadap persentase peserta aktif alat KB suntik dengan $R$-Square dari model adalah sebesar $85,87 \%$.
\end{abstract}

Kata Kunci-Jawa Timur, KB, kontrasepsi, Spline, Suntik, Truncated.

\section{PENDAHULUAN}

$\mathrm{F}$ ERTILITAS merupakan salah satu faktor utama yang memengaruhi tingkat pertumbuhan penduduk di Indonesia. Salah satu upaya Pemerintah Indonesia untuk mengendalikan laju pertumbuhan penduduk adalah melalui pengendalian fertilitas di Indonesia dengan cara menerapkan program Keluarga berencana (KB). Keluarga berencana adalah upaya untuk mewujudkan keluarga yang berkualitas dengan cara menentukan usia kawin yang ideal, mengatur jumlah, jarak, dan usia ideal dalam melahirkan anak, mengatur kehamilan dan membina ketahanan serta kesejahteraan anak [1]. Program KB ditandai dengan pemakaian alat kontrasepsi untuk menghindari "4 terlalu" seperti terlalu tua, terlalu muda, terlalu banyak anak, dan terlalu dekat jarak kelahiran [2]. Suntik KB merupakan salah satu alat kontrasepsi yang meningkat peminatnya dan dianggap cukup ideal. Alat kontrasepsi berupa pemberian suntikan merupakan salah satu alat kontrasepsi hormonal yang mencegah terjadinya kehamilan dengan melalui suntikan hormonal. Tingkat kegagalan kontrasepsi suntik dapat dilihat dari angka kegagalan yang kurang dari $0,1 \%$ per tahun [3].

Di daerah Jawa Timur sendiri, penggunaan kontrasepsi jenis suntik juga menduduki peringkat pertama atau terbanyak yang digunakan masyarakat Jawa Timur. Menurut data yang dihimpun oleh Badan Kependudukan dan Keluarga Berencana (BKKBN) Jawa Timur pengguna KB suntik pada tahun 2016 mencapai angka 58,7\%, KB Pil sebanyak $20,68 \%$ dan pengguna alat kontrasepsi yang lain dibawah $10 \%$. Karena tingginya pemakaian alat KB suntik di Jawa Timur, maka akan dilakukan penelitian mengenai faktor-faktor yang memengaruhi peserta aktif KB di Jawa Timur memilih KB suntik untuk metode kontrasepsi yang dipakai.

Analisis regresi merupakan suatu metode statistika yang digunakan untuk mengukur ada atau tidaknya hubungan antara variabel respon dan variabel prediktor [4][5]. Tidak setiap data diketahui bentuk polanya. Pada kasus dimana pola data tidak diketahui maka dapat digunakan regresi semiparametrik dan regresi nonparametrik. Regresi semiparametrik digunakan untuk mengetahui pola hubungan antara variabel respon dan prediktor dimana sebagian pola data diketahui bentuknya dan sebagian lagi tidak [6]. Sedangkan, regresi nonparametrik merupakan salah satu analisis regresi dimana data akan mencari bentuk estimasi dari kurva regresinya, tanpa harus dipengaruhi oleh faktor subyektifitas peneliti [7]. Salah satu pendekatan regresi nonparametrik yang sering digunakan adalah regresi nonparametrik spline truncated. Regresi nonparametrik spline truncatedmerupakan metode yang paling banyak digunakan pada regresi nonparametrik. Bentuk kurva Spline terpotong-potong sehingga mampu mengatasi perubahan pola data pada sub interval tertentu. Pada metode regresi nonparametrik Spline Truncateddigunakan bantuan titiktitik knot [8][9]. Selain itu, Spline memiliki kelebihan yakni model akan cenderung mencari estimasinya kemanapun data tersebut akan bergerak [10][11].

Pada laporan ini akan dibahas tentang pemodelan faktorfaktor yang memengaruhi persentase peserta KB aktif dengan menggunakan metode kontrasepsi suntik di Provinsi Jawa Timur pada tahun 2016 dengan menggunakan metode regresi nonparametrik spline truncated. Tujuan dari penelitian ini adalah model yang didapatkan diharapkan dapat memberikan informasi terkait faktor-faktor yang diduga mempengaruhi persentase peserta $\mathrm{KB}$ aktif metode kontrasepsi suntik di Provinsi Jawa Timur. 


\section{TINJAUAN PUSTAKA}

\section{A. Regresi Nonparametrik Spline Truncated}

Regresi nonparametrikspline merupakan modifikasi dari fungsi polinomial tersegmen yang sangat dipengaruhi oleh penentuan lokasi titik knot [12][13]. Regresi nonparametrik spline truncatedmerupakanmetode yang paling banyak digunakan pada regresi nonparametricspline. Pada metode regresi nonparametrik spline truncateddigunakan bantuan titik-titik knot. Dalam analisis regresi nonparametrik Spline Truncated, apabila terdapat satu variabel respon dan satu variabel prediktor maka dinamakan regresi nonparametrik Spline Truncated univariabel. Sedangkan jika terdapat satu variabel respon dengan lebih dari satu variabel prediktor maka disebut regresi nonparametrik Spline Truncated multivariable [14]. Diberikan data berpasangan $\left(x_{1 i}, x_{2 i}, \ldots, x_{p i}, y_{i}\right), i=1,2, \ldots, n$ dan hubungan kedua data tersebut diasumsikan mengikuti model regresi nonparametrikdengan persamaan sebagai berikut [15]:

$$
y_{i}=f\left(x_{1 i}, x_{2 i}, \ldots, x_{p i}\right)+\varepsilon_{i}, i=1,2, \ldots, n
$$

dimana error random $\varepsilon_{i}$ diasumsikan identik, independen, dan berdistribusi normal dengan $E\left(\varepsilon_{i}\right)=0$ dan $\operatorname{var}\left(\varepsilon_{i}\right)=\sigma^{2}$ - Apabila kurva regresi $f$ merupakan model aditif, maka dapat dijabarkan menjadi:

$$
\begin{aligned}
f\left(x_{1 i}, x_{2 i}, \ldots, x_{p i}\right) & =f_{1}\left(x_{1 i}\right)+f_{2}\left(x_{2 i}\right)+\ldots+f_{p}\left(x_{p i}\right) \\
& =\sum_{j=1}^{p} f_{j}\left(x_{j i}\right), i=1,2, \ldots, n
\end{aligned}
$$

Fungsi SplineTruncated diperoleh berdasarkan penjumlahan antara fungsi polinomial dengan fungsi Truncated. Kurva regresi $f_{j}\left(x_{j}\right)$ diasumsikan termuat pada ruang Spline berorde $m$ dengan titik-titik knot $K_{1 j}, K_{2 j}, \ldots, K_{r j} ; j=1,2, \ldots, p$ diberikan oleh persamaan berikut:

$$
f_{j}\left(x_{j}\right)=\sum_{k=0}^{m} \beta_{j k} x_{j}{ }^{k}+\sum_{u=1}^{r} \beta_{j(m+u)}\left(x_{j}-K_{j u}\right)_{+}^{m}
$$

Sehingga diperoleh persamaan model regresi nonparametrik Spline Truncated multivariabel pada persamaan (4).

$$
y_{i}=\sum_{j=1}^{p} \sum_{k=0}^{m} \beta_{j k} x_{j}^{k}+\sum_{j=1}^{p} \sum_{u=1}^{r} \beta_{j(m+u)}\left(x_{j}-K_{j u}\right)_{+}^{m}+\varepsilon_{i}, i=1,2, \ldots, n
$$

Fungsi $\left(x_{j}-K_{j u}\right)_{+}^{m}$ merupakan fungsi Truncated (potongan) yang diberikan oleh :

$$
\left(x_{j}-K_{j u}\right)_{+}^{m}= \begin{cases}\left(x_{j}-K_{j u}\right)^{m}, & x_{j} \geq K_{j u} \\ 0 \quad & , x_{j}<K_{j u}\end{cases}
$$

dengan

$$
\beta_{j k} \quad \text { :parametermodel } \quad \text { polinomial, } k=0,1, \ldots, m
$$

$$
j=1,2, \ldots, p
$$

$x_{j i}$ : variabel prediktor $j \mathrm{ke}-i, i=1,2, \ldots, n$

$\beta_{j(m+u)}$ : parameter komponen Truncated, $u=1,2, \ldots, r$

$r$ : banyak knot

$K_{j u} \quad:$ titik-titik knot

\section{B. Estimasi Parameter}

Ordinary Least Square (OLS) adalah salah satu metode yang biasa digunakan untuk mengestimasi parameter model regresi nonparametrik spline. Metode ini mengestimasi parameter dengan cara meminimumkan jumlah kuadrat residual. Berikut adalah bentuk matriks dari model regresi nonparametrik spline linear dengan $K$ knot dan univariabel predictor [4].

$$
\underset{\sim}{\mathbf{y}}=\mathbf{X} \boldsymbol{\sim}+\underset{\sim}{\boldsymbol{g}}
$$

Dimana,

$\underset{\sim}{\mathbf{y}}=\left[\begin{array}{c}y_{1} \\ y_{2} \\ \vdots \\ y_{n}\end{array}\right], \underset{\sim}{\boldsymbol{\beta}=}\left(\begin{array}{c}\beta_{0} \\ \beta_{11} \\ \vdots \\ \beta_{1 m} \\ \beta_{1(m+1)} \\ \vdots \\ \beta_{1(m+r)} \\ \vdots \\ \beta_{p(m+1)} \\ \vdots \\ \beta_{p(m+r)}\end{array}\right), \underset{\sim}{\boldsymbol{\varepsilon}}=\left(\begin{array}{c}\varepsilon_{1} \\ \varepsilon_{2} \\ \vdots \\ \varepsilon_{n}\end{array}\right)$

$\mathbf{X}=\left(\begin{array}{cccccccccccc}1 & x_{11} & x_{11}{ }^{2} & \cdots & x_{11}{ }^{m} & \left(x_{11}-K_{11}\right)_{+}^{m} & \cdots & x_{p 1} & x_{p 1}{ }^{2} & \cdots & x_{p 1}{ }^{m} & \left(x_{p 1}-K_{p r}\right)_{+}^{m} \\ 1 & x_{12} & x_{12}{ }^{2} & \cdots & x_{12}{ }^{m} & \left(x_{12}-K_{11}\right)_{+}^{m} & \cdots & x_{p 2} & x_{p 2}{ }^{2} & \cdots & x_{p 2}{ }^{m} & \left(x_{p 2}-K_{p r}\right)_{+}^{m} \\ \vdots & \vdots & \vdots & \ddots & \vdots & \vdots & \ddots & \vdots & \vdots & \ddots & \vdots & \vdots \\ 1 & x_{1 n} & x_{1 n}{ }^{2} & \cdots & x_{12}{ }^{m} & \left(x_{1 n}-K_{11}\right)_{+}^{m} & \cdots & x_{p n} & x_{p n}{ }^{2} & \cdots & x_{p n}{ }^{m} & \left(x_{p n}-K_{p r}\right)_{+}^{m}\end{array}\right)$

Dari persamaan (6), residual dapat ditulis menjadi bentuk persamaan berikut.

$$
\underset{\sim}{\boldsymbol{\varepsilon}}=\underset{\sim}{\mathbf{y}}-\mathbf{X} \boldsymbol{\sim}
$$

Jumlah kuadrat residual dalam matriks dapat ditulis sebagai berikut :

$$
\begin{aligned}
\sum_{i=1}^{n} \varepsilon_{i}^{2} & ={\underset{\sim}{\boldsymbol{\varepsilon}}}^{\mathbf{\varepsilon}} \\
& =\underset{\sim}{\mathbf{y}}{\underset{\sim}{\mathbf{y}}-2 \underset{\sim}{\boldsymbol{\beta}}}^{\prime} \mathbf{X}^{\prime} \underset{\sim}{\mathbf{y}}+\underset{\sim}{\boldsymbol{\beta}} \mathbf{X}^{\prime} \mathbf{X} \underset{\sim}{\boldsymbol{\beta}}
\end{aligned}
$$

Untuk meminimumkan $\underset{\sim}{\mathbf{\varepsilon}} \underset{\sim}{\mathbf{\varepsilon}}$ maka turunan pertama terhadap $\boldsymbol{\beta}$ harus sama dengan nol, sehingga didapatkan nilai estimasi $\operatorname{parameter}(\underset{\sim}{\hat{\boldsymbol{\beta}}})$ sebagai berikut:

$$
\hat{\boldsymbol{\beta}}=\left(\mathbf{X}^{\prime} \mathbf{X}\right)^{-\mathbf{1}} \mathbf{X}^{\prime} \mathbf{y}
$$

\section{Pemilihan Titik Knot Optimum}

Model regresi spline terbaik merupakan model yang memiliki titik knot optimal. Knot merupakan titik dari sebuah garis regresi untukmembentuk region dari suatu fungsi regresi [16]. Pada data longitudinal titik knot optimum dapat dicari dengan menggunakan pendekatan penalized regression [17]. Namun, untuk data cross section, salah satu metode yang biasa digunakan adalah metode Generalized Cross Validation (GCV). Model regresi spline terbaik diperoleh dari titik knot optimal dengan melihat nilai GCV terkecil. Metode GCV dapat dituliskan sebagai berikut [18].

$$
G C V(K)=\frac{\operatorname{MSE}(K)}{\left[n^{-1} \operatorname{trace}(\mathbf{I}-\mathbf{A})\right]^{2}}
$$

dimana Imerupakan matriks identitas, $n$ adalah jumlah pengamatan, Kmerupakan titik-titik knot,

$$
\operatorname{MSE}(K)=n^{-1} \sum_{i=1}^{n}\left(y_{i}-\hat{y}\right)^{2}
$$

serta $A=\mathbf{X}\left(\mathbf{X}^{\prime} \mathbf{X}\right)^{-1} \mathbf{X}^{\prime}$ 


\section{Pengujian Parameter Secara Serentak}

Uji serentak dilakukan untuk mengetahui signifikansi parameter model regresi secara bersama. Pengujian parameter model secara serentak dapat disajikan menggunakan Analysis of Variance (ANOVA) yang disajikan dalam Tabel 2.1 sebagai berikut :

Tabel 1.

Analysis of Variance Uji Parameter Secara Serentak

\begin{tabular}{lcccc}
\hline \hline $\begin{array}{c}\text { Sumber } \\
\text { variasi }\end{array}$ & Df & $\begin{array}{c}\text { Sum of Square } \\
(\mathrm{SS})\end{array}$ & $\begin{array}{c}\text { Mean } \\
\text { Square } \\
(\mathrm{MS})\end{array}$ & $F_{\text {hitung }}$ \\
\hline Regresi & $p+r$ & $\sum_{i=1}^{n}\left(\hat{y}_{i}-\bar{y}\right)^{2}$ & $\frac{S S_{\text {regresi }}}{d f_{\text {regresi }}}$ & \\
Error & $n-(p+r)-1$ & $\sum_{i=1}^{n}\left(y_{i}-\hat{y}_{i}\right)^{2}$ & $\frac{S S_{\text {error }}}{d f_{\text {error }}}$ & $\frac{M S_{\text {regresi }}}{M S_{\text {error }}}$ \\
& $n-1$ & $\sum_{i=1}^{n}\left(y_{i}-\bar{y}\right)^{2}$ & & \\
Total & $n-1$ & & \\
\hline \hline
\end{tabular}

Perumusan hipotesis uji serentak adalah:

$\mathrm{H}_{0}: \beta_{1}=\beta_{2}=\ldots=\beta_{p+r}=0$

$\mathrm{H}_{1}$ : minimal ada satu $\beta_{j} \neq 0 ; j=1,2, \ldots, p+r$

Nilai $p+r$ merupakan banyak parameter dalam model regresi nonparametrik spline truncated kecuali $\beta_{0}$. Tolak $\mathrm{H}_{0}$ jika $\quad F_{\text {hitung }}>F_{\alpha(p ; n-p-1)}$ atau $\quad p$-value $<\alpha \quad$ sehingga menghasilkan kesimpulan bahwa minimal ada satu variabel yang berpengaruh signifikan terhadap variabel respon [4]. Untuk itu harus dilanjutkan pengujian secara parsial yang berfungsi untuk mengetahui parameter dari setiap variabel prediktor yang berpengaruh secara signifikan.

\section{E. Pengujian Parameter Secara Parsial}

Pengujian secara individu berfungsi untuk mendeteksi apakah parameter secara individual mempunyai pengaruh yang signifikan terhadap variabel respon.

Perumusan Hipotesis:

$$
\begin{aligned}
& \mathrm{H}_{0}: \beta_{j}=0 \\
& \mathrm{H}_{1}: \beta_{j} \neq 0, \mathrm{j}=1,2, \ldots, p+r
\end{aligned}
$$

Pengujian secara individu dilakukan dengan menggunakan uji $t$ [4]. Statistik uji yang digunakan adalah sebagai berikut:

$$
t_{\text {hitung }}=\frac{\hat{\beta}_{j}}{S E\left(\widehat{\beta}_{j}\right)}
$$

dimana $S E\left(\hat{\beta}_{j}\right)$ adalah standart error $\hat{\beta}_{j}$ yang diperoleh dari akar elemen diagonal ke- $j$ dari matriks yang dapat diurai seperti berikut :

$$
\begin{aligned}
\operatorname{Var}(\underset{\sim}{\hat{\boldsymbol{\beta}}}) & =\operatorname{var}\left[\left(\mathbf{X}^{\prime} \mathbf{X}\right)^{-1} \mathbf{X}^{\prime} \underset{\sim}{\mathbf{y}}\right] \\
& \left.=\left(\mathbf{X}^{\prime} \mathbf{X}\right)^{-1} \mathbf{X}^{\prime} \operatorname{var} \underset{\sim}{\mathbf{y}}\right)\left[\left(\mathbf{X}^{\prime} \mathbf{X}\right)^{-1} \mathbf{X}^{\prime} \mathbf{X}\right]^{\prime} \\
& =\left(\mathbf{X}^{\prime} \mathbf{X}\right)^{-1} \mathbf{X}^{\prime}\left(\sigma^{2} \mathrm{I}\right) \mathbf{X}\left(\mathbf{X}^{\prime} \mathbf{X}\right)^{-1} \\
& =\sigma^{2}\left(\mathbf{X}^{\prime} \mathbf{X}\right)^{-1} \mathbf{X}^{\prime} \mathbf{X}\left(\mathbf{X}^{\prime} \mathbf{X}\right)^{-1} \\
& =\sigma^{2}\left(\mathbf{X}^{\prime} \mathbf{X}\right)^{-1}
\end{aligned}
$$

Dengan $\sigma^{2}$ adalah Mean Square Error (MSE) dari uji parameter secara serentak. Tolak $\mathrm{H}_{0}$ jika $\left|t_{\text {hitung }}\right|>t_{a / 2 ;(n-p-1)}$ atau $p$-value $<\alpha$. Sehingga menghasikan kesimpulan bahwa variabel prediktor ke-n berpengaruh signifikan terhadap variabel respon.

\section{F. Koefisien Determinasi}

Koefisien determinasi adalah kuantitas yang dapat menjelaskan sumbangan variabel prediktor terhadap variabel respon. Semakin tinggi nilai $\mathrm{R}^{2}$ yang dihasilkan suatu model, maka semakin baik pula variabel-variabel prediktor dalam model tersebut dalam menjelaskan variabilitas variabel respon [4]. Berikut ini adalah rumus untuk mendapatkan nilai $\mathrm{R}^{2}$.

$$
\mathrm{R}^{2}=\frac{S S_{\text {Re gresi }}}{S S_{\text {total }}}=\frac{\sum_{i=1}^{n}\left(\hat{y}_{i}-\bar{y}\right)^{2}}{\sum_{i=1}^{n}\left(y_{i}-\bar{y}\right)^{2}}
$$

Pemilihan model juga akan menunjukkan banyaknya parameter yang digunakan dalam model tersebut. Seperti yang dijelaskan dalam prinsip parsimoni, suatu model regresi yang baik adalah model regresi dengan banyak parameter yang sesedikit mungkin tetapi mempunyai $\mathrm{R}^{2}$ yang cukup tinggi.

\section{G. Pengujian Asumsi Residual}

Pengujian asumsi residual (Goodness of fit) dilakukan untuk mengetahui apakah residual yang dihasilkan telah memenuhi asumsi yakni identik, independen, dan berdistribusi normal atau $\varepsilon_{i} \sim \operatorname{iidN}\left(0, \sigma^{2}\right)$. Asumsi identik terpenuhi jika varians antar residual homogen dan tidak terjadi heteroskedastisitas [19]. Asumsi klasik kedua yang harus dipenuhi adalah tidak terdapat korelasi antar residual yang ditunjukkan oleh nilai kovarian antara $\varepsilon_{i}$ dan $\varepsilon_{j}$ sama dengan nol. Uji asumsi distribusi normal dapat dilakukan menggunakan uji Kolmogorov-smirnov [20]. Berikut adalah asumsi-asumsi yang harus dipenuhi.

1. Asumsi Identik

Asumsi identik atau biasa juga disebut homoskedastisitas yang berarti bahwa varians pada residual adalah identik. Kebalikanannya adalah kasus heteroskedastisitas, yaitu jika kondisi varians residual tidak identik [19].

$$
\operatorname{var}\left(y_{i}\right)=\operatorname{var}\left(\varepsilon_{i}\right)=\sigma^{2} ; i=1,2, \ldots, n
$$

Uji identik dapat menggunakan uji Glejser. Perumusan hipotesisnya adalah sebagai berikut:

$\mathrm{H}_{0}: \sigma_{1}^{2}=\sigma_{2}^{2}=\ldots=\sigma_{n}^{2}=\sigma^{2}$

$\mathrm{H}_{1}$ : Minimal ada satu $\sigma_{i}^{2} \neq \sigma^{2} ; i=1,2, \ldots, n$

Statistik uji yang digunakan adalah,

$$
F_{\text {hitung }}=\frac{\sum_{i=1}^{n}\left(\left|\hat{\varepsilon}_{i}\right|-|\bar{\varepsilon}|\right)^{2} / p-1}{\sum_{i=1}^{n}\left(\left|\varepsilon_{i}\right|-\left|\hat{\varepsilon}_{i}\right|\right)^{2} / n-p-1}
$$

Tolak $\mathrm{H}_{0}$ jika $F_{\text {hitung }}>F_{a ;(p-1, n-p-1)}$ atau $p-$ value $<\alpha$ yang berarti bahwa terdapat kasus heteroskedastisitas [4].

2. Asumsi Independen

Asumsi independen merupakan asumsi dari model regresi yang mengharuskan tidak terdapat korelasi antar residual. Uji yang digunakan untuk mendeteksi kasus autokorelasi adalah uji Durbin-Watson[4]. Perumusan hipotesis yang digunakan adalah, 
$\mathrm{H}_{0}$ : tidak terjadi autokorelasi

$\mathrm{H}_{1}$ : terjadi autokorelasi

Statistik uji:

$$
d=\frac{\sum_{i=1}^{n}\left(\varepsilon_{i}-\varepsilon_{i-1}\right)^{2}}{\sum_{i=1}^{n} \varepsilon_{i}^{2}}
$$

Dengan taraf signifikansi $5 \%$, berikut beberapa keputusan setelah membandingkan dengan tabel Durbin-Watson (DW):

a. $d<d_{L}$, tolak $\mathrm{H}_{0}$ yang berarti terjadi autokorelasi positif.

b. $d_{L}<d<d_{U}$, tidak dapat disimpulkan (inconclusive).

c. $d_{U}<d<4-d_{U}$, gagal tolak $\mathrm{H}_{0}$ yang berarti tidak terjadi autokorelasi.

d. $4-d_{U}<d<4-d_{L}$, tidak dapat disimpulkan (inconclusive).

e. $d>4-d_{L}$, tolak $\mathrm{H}_{0}$ yang berarti terjadi autokorelasi negatif.

3. Uji Normalitas Kolmogorov-Smirnov

Uji Kolmogorov-Smirnov dilakukan untuk mengetahui apakah suatu data telah mengikuti suatu distribusi tertentu. Perumusan hipotesis yang digunakan adalah [20] :

$\mathrm{H}_{0}: F_{n}(x)=F_{n}(x)$ (residual berdistribusi normal)

$\mathrm{H}_{1}: F_{n}(x) \neq F_{n}(x)$ (residual tidak berdistribusi normal)

Statistik uji yang digunakan adalah sebagai berikut:

$$
D=\underset{x}{\operatorname{Sup}}\left|F_{n}(x)-F_{0}(x)\right|
$$

$F_{n}(x)$ merupakan nilai peluang kumulatif(fungsi distribusi kumulatif)berdasarkan data sampel, sedangkan $F_{0}(x)$ adalah nilai peluang kumulatif(fungsi distribusi kumulatif)dibawah $\mathrm{H}_{0}$. Tolak $\mathrm{H}_{0}$ apabila $D>D_{\alpha} . D_{\alpha}$ adalah nilai kritis untuk uji Kolmogorov Smirnovyang diperoleh dari tabel Kolmogorov Smirnovatau $p$-value $<\alpha$.

\section{H. KB Suntik}

Suntik merupakan salah satu alat kontrasepsi yang disarankan oleh pemerintah melalui program KB. Terdapat dua jenis kontrasepsi suntik yaitu suntik KB 1 bulan dan suntik KB 3 bulan atau biasa disebut Depo Medroxyprogesterone Acetate (DMPA). Dari hasil Survei Demografi dan Kesehatan Indonesia (SDKI) tahun 2012 penggunaan $\mathrm{KB}$ di Indonesia didominasi oleh penggunaan kontrasepsi jenis suntik (32\%). Di daerah Jawa Timur, penggunaan kontrasepsi jenis suntik juga menduduki peringkat pertama atau terbanyak yang digunakan masyarakat Jawa Timur. Menurut data yang dihimpun oleh Badan Kependudukan dan Keluarga Berencana (BKKBN) Jawa Timur pengguna KB suntik pada tahun 2016 mencapai angka $58,7 \%$.

\section{METODOLOGI PENELITIAN}

\section{A. Sumber Data}

Sumber data yang digunakan dalam penelitian ini adalah data sekunder dengan unit penelitian adalah 38 Kabupaten/Kota di Provinsi Jawa Timur yang diperoleh dari buku publikasi Badan Pusat Statistik (BPS) yaitu "Statistik Kesejahteraan Rakyat Provinsi Jawa Timur 2016”.

\section{B. Variabel Penelitian}

Variabel yang digunakan dalam penelitian ini terdiri dari variabel respon (Y) yaitu persentase peserta KB aktif Metode Kontrasepsi Suntik setiap kabupaten/kota di Provinsi Jawa Timur tahun 2016 dan beberapa variabel prediktor (X) yang meliputi faktor-faktor yang diduga mempengaruhi peserta KB aktif Metode Kontrasepsi Suntik di Provinsi Jawa Timur tahun 2016. Variabel prediktor (X) yang digunakan diambil berdasarkan beberapa penelitian terdahulu, berikut adalah variabel yang digunakan dalam penelitian ini.

Tabel 2.Variabel Penelitian

\begin{tabular}{clc}
\hline Variabel & \multicolumn{1}{c}{ Keterangan } & Skala \\
\hline $\mathrm{Y}$ & $\begin{array}{l}\text { Persentase Peserta KB Aktif Kontrasepsi } \\
\text { Suntik }\end{array}$ & Rasio \\
\hline $\mathrm{X}_{1}$ & $\begin{array}{l}\text { Persentase penduduk perempuan berstatus } \\
\text { kawin usia 15 - 49 tahun dan menggunakan } \\
\text { alat KB }\end{array}$ & Rasio \\
\hline & Persentase jumlah anak lahir hidup lebih dari & Rasio \\
& 2 dari setiap perempuan usia 15 - 49 tahun & \\
$\mathrm{X}_{2}$ & $\begin{array}{l}\text { yang berstatus kawin serta menggunakan alat } \\
\text { KB }\end{array}$ & \\
\hline & $\begin{array}{l}\text { Persentase perempuan usia 15 - 49 tahun } \\
\text { dengan pendidikan tertinggi yang ditamatkan }\end{array}$ & \\
$\mathrm{X}_{3}$ & $\begin{array}{l}\text { lebih dari atau sama dengan SLTA/sederajat } \\
\text { dan menggunakan KB }\end{array}$ & \\
\hline & $\begin{array}{l}\text { Persentase perempuan dengan usia kawin } \\
\text { pertama lebih dari atau sama dengan 19 } \\
\text { tahun. }\end{array}$ & Rasio \\
\hline
\end{tabular}

\section{Langkah Penelitian}

Langkah-langkah analisis dalam penelitian ini adalah sebagai berikut.

1. Menganalisis karakteristik persentase peserta KB aktif Suntik berdasarkan faktor-faktor yang diduga berpengaruh di Provinsi Jawa Timur tahun 2016 dengan unit pengamatan yaitu 38 kabupaten/kota menggunakan statistika deskriptif. 2. Pemodelan persentase Peserta KB Aktif yang menggunakan alat kontrasepsi suntik:

a. Membuat scatter plot antara variabel respon dengan masing-masing variabel prediktor untuk mengidentifikasi pola data yang terbentuk.

b. Memodelkan data menggunakan pendekatan spline truncated dengan satu, dua, tiga, serta kombinasi titik knot.

c. Memilih titik knot optimum berdasarkan nilai GCV yang paling kecil (minimum).

d. Membuat model regresi nonparametrik spline truncated dengan titik knot optimum.

e. Melakukan pengujian signifikansi parameter yang dilakukan melalui dua tahapan, yaitu pengujian secara serentak dan parsial.

f. Melakukan pengujian asumsi residual identik, independen, dan distribusi normal (IIDN) dari model regresi nonparametrik spline truncated yang telah terbentuk. g. Mengintepretasikan model dan menarik kesimpulan

\section{ANALISIS DAN PEMBAHASAN}

\section{A. Karakteristik Data}

Pemakaian alat KB suntik di Jawa Timur memiliki peminat paling banyak dibanding alat $\mathrm{KB}$ lain. Berikut adalah karakteristik dari persentase peserta aktif alat $\mathrm{KB}$ suntik beserta variabel-variabel yang diduga memengaruhinya di Jawa Timur menurut kabupaten/kota. 
Tabel 3.

Karakteristik Variabel

\begin{tabular}{ccccc}
\hline \hline Variabel & Mean & Variance & Minimum & Maksimum \\
\hline $\mathrm{Y}$ & 55,92 & 180,31 & 27,15 & 80,91 \\
$\mathrm{X}_{1}$ & 26,07 & 7,40 & 19,23 & 33,04 \\
$\mathrm{X}_{2}$ & 20,50 & 35,54 & 12,52 & 40,19 \\
$\mathrm{X}_{3}$ & 21,68 & 82,59 & 5,41 & 41,58 \\
$\mathrm{X}_{4}$ & 44,15 & 75,87 & 22,12 & 58,06 \\
\hline \hline
\end{tabular}

Tabel 3 menunjukkan karakteristik data dari persentase peserta aktif KB suntik dan variabel-variabel prediktor yang di duga memengaruhinya. Diketahui bahwa rata-rata peserta aktif KB suntik di Jawa Timur berdasarkan kabupaten/kota adalah 55,92 persen, artinya dari 100 orang perempuan berusia 15 - 49 tahun yang menggunakan alat $\mathrm{KB}$ rata-rata 55 hingga 56 orang perempuan menggunakan alat $\mathrm{KB}$ suntik. Namun, varaians dari peserta aktif KB suntik juga tinggi yaitu sebesar 180,31 persen.

Dari keempat variabel prediktor, variabel persentase perempuan usia 15-49 tahun dengan pendidikan yang ditamatkan lebih dari atau sama dengan SLTA/sederajat $\left(\mathrm{X}_{3}\right)$ memiliki varians tertinggi yaitu sebesar 82,59 persen.

\section{B. Pola Hubungan Variabel Respon dan Variabel Prediktor}

Identifikasi pola hubungan antar variabel prediktorterhadap variabel respon dilakukan untuk mengetahui bagaimana pola hubungan masing-masing variabel prediktor terhadap variabel respon. Berikut adalah gambaran pola hubungan antar masing-masing variabel prediktor terhadap variabelrespon.

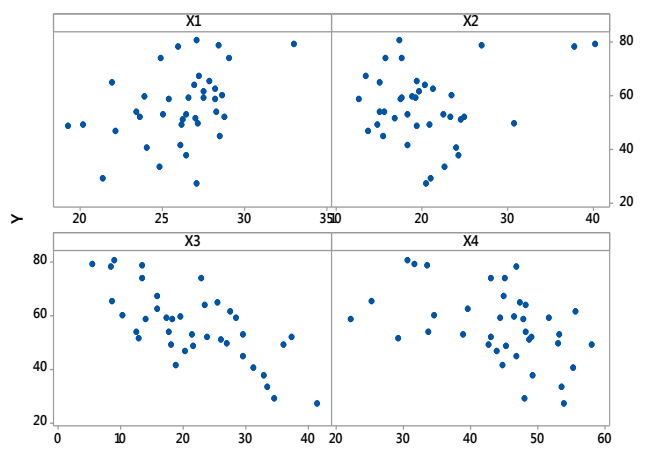

Gambar 1.Scatter Plot Setiap Variabel Prediktor Terhadap Variabel Respon.

Gambar 1 menunjukkan scatter plot atau pola hubungan terbentuk dari variabel prediktor terhadap variabel respon yaitu persentase peserta aktif KB suntik di Provinsi Jawa Timur menurut kabupaten/kota. Dari Gambar 1 terlihat bahwa pola hubungan yang terbentuk antara setiap variabel prediktor dengan variabel respon tersebut secara visual tidak membentuk pola tertentu.

\section{Pemilihan Titik Knot Optimum}

Titik knot optimum diperoleh dari nilai GCV yang paling minimum. Pemilihan titik knot optimum pada variabel-variabel yang diduga mempengaruhi persentase peserta aktif KB suntik di Jawa Timur dengan metode GCV dimulai dengan menggunakansatutitikknot, kemudian dua titik knot, tiga titik knot dan yang terakhir adalah kombinasi dari satu, dua, dan tiga titik knot.

Berikut adalah hasil rangkuman GCV minimumuntuk regresi nonparametrik spline truncated dengan menggunakan satu titik knot, dua titik knot, tiga titik knot dan kombinasi knot.
Tabel 4.

NilaiGCV Minimumpada Setiap Knot

\begin{tabular}{|c|c|c|c|c|c|}
\hline Titik Knot & $\mathrm{X}_{1}$ & $\mathrm{X}_{2}$ & $\mathrm{X}_{3}$ & $\overline{X_{4}}$ & GCV \\
\hline 1 & 31,91 & 37,93 & 38,63 & 55,13 & 110,57 \\
\hline \multirow{3}{*}{2} & 25,15 & 24,38 & 20,91 & 37,52 & \multirow{3}{*}{91,33} \\
\hline & 25,43 & 24,94 & 21,65 & 38,26 & \\
\hline & 25,15 & 24,38 & 20,91 & 37,52 & \\
\hline \multirow[t]{3}{*}{3} & 25,71 & 25,51 & 22,39 & 38,99 & \multirow[t]{3}{*}{73,19} \\
\hline & 31,63 & 37,37 & 37,89 & 54,39 & \\
\hline & 31.91 & 24.38 & 20.91 & 37.52 & \\
\hline \multirow[t]{2}{*}{ Kombinasi } & & 25.51 & 22.39 & 38.99 & \multirow[t]{2}{*}{67,68} \\
\hline & & 37.37 & 37.89 & 54.39 & \\
\hline
\end{tabular}

Tabel 4 menunjukkan hasil ringkasan dari nilai GCV minimum untuk pemilihan titik knot pada satu titik knot, dua titik knot, tiga titik knot, dan kombinasi knot. Pemodelan yang dipilih dilihat dari nilai GCV paling minimum. Dari Tabel 4 diketahui bahwa nilai GCV yang paling minimum adalah GCV dari kombinasi knot 1-3-3-3, sehingga digunakan model regresi nonparametrik spline truncated dengan kombinasi knot 1-3-3-3 pada empat variabel prediktor yang diduga memengaruhi persentase peserta aktif KB suntik di Provinsi Jawa Timur. berikut adalah model yang terbentuk.

$$
\begin{aligned}
\hat{y}= & \hat{\beta}_{0}+\hat{\beta}_{1} x_{1}+\hat{\beta}_{2}\left(x_{1}-K_{1}\right)_{+}^{1}+\hat{\beta}_{3} x_{2}+\hat{\beta}_{4}\left(x_{2}-K_{2}\right)_{+}+ \\
& \hat{\beta}_{5}\left(x_{2}-K_{3}\right)_{+}+\hat{\beta}_{7}\left(x_{2}-K_{4}\right)_{+}+\hat{\beta}_{8} x_{3}+\hat{\beta}_{9}\left(x_{3}-K_{5}\right)_{+}+ \\
& \hat{\beta}_{10}\left(x_{3}-K_{6}\right)_{+}+\hat{\beta}_{11}\left(x_{3}-K_{7}\right)_{+}+\hat{\beta}_{12} x_{4}+\hat{\beta}_{13}\left(x_{4}-K_{8}\right)_{+}+ \\
& \hat{\beta}_{14}\left(x_{4}-K_{9}\right)_{+}+\hat{\beta}_{15}\left(x_{4}-K_{10}\right)_{+}
\end{aligned}
$$

\section{Penaksiran Parameter Model}

Model regresi nonparametrik spline truncated terbaik terbentuk dari pemilihan titik knot optimum. Berdasarkan tahapan pemilihan titik knot optimum yang telah dilakukan sebelumnya, didapatkan titik knot optimum adalah dengan menggunakan kombinasi titik knot yaitu 1-3-3-3. Hasil estimasi parameter dengan menggunakan kombinasi knot adalah sebagai berikut.

$$
\begin{aligned}
\hat{y} & =116,01+0,49 x_{1}-353,40\left(x_{1}-31,91\right)_{+}-0,87 x_{2}+42,57\left(x_{2}-24,38\right)_{+}+ \\
& -51,02\left(x_{2}-25,51\right)_{+}+172,76\left(x_{2}-37,37\right)_{+}-3,73 x_{3}+20,89\left(x_{3}-20,91\right)_{+}+ \\
& -19,69\left(x_{3}-22,39\right)_{+}^{1}+2,58\left(x_{3}-37,89\right)_{+}-0,37 x_{4}+15,75\left(x_{4}-37,52\right)_{+}+ \\
& -15,52\left(x_{4}-38,99\right)_{+}+5,81\left(x_{4}-54,39\right)_{+}
\end{aligned}
$$

Model regresi spline truncated dengan kombinasi knot ini memiliki $\mathrm{R}^{2}$ sebesar $85,87 \%$. Nilai $\mathrm{R}^{2}$ memiliki arti bahwa model regresi spline truncated tersebut dapat menjelaskan variabilitas dari persentase peserta aktif $\mathrm{KB}$ suntik di Provinsi Jawa Timur sebesar 85,87\%.

\section{E. Pengujian Parameter Model}

Pengujian parameter regresi nonparametrik spline truncated bertujuan untuk mengetahui apakah varabelvariabel prediktor yang dihasilkan dari pemodelan memiliki pengaruh yang signifikan terhdap persentase peserta aktif KB suntik di Provinsi Jawa Timur. Berikut adalah tahapan yang dilakukan dalam pengujian parameter model regresi nonparametri spline truncated.

1. Pengujian parameter model secara serentak

Pengujian parameter model secara serentak ini dilakukan untuk mengetahui signifikansi pengaruh 4 variabel prediktor terhadap persentase peserta aktif KB suntik secara serentak. Hipotesis dalam pengujian ini adalah sebagai berikut.

Tabel 5.

ANOVA Pengujian Parameter Secara Serentak

\begin{tabular}{ccccc}
\hline \hline Sumber & df & SS & MS & F $_{\text {hit }}$ \\
\hline Regresi & 14 & 5729,33 & 409,24 & 9,99 \\
Error & 23 & 942,21 & 40,97 & \\
Total & 37 & 6671,54 & & \\
\hline \hline
\end{tabular}


Tabel 5 menunjukkan ANOVA hasil pengujian parameter secara serentak. Diambil keputusan tolak H0 jika Fhitung lebih besar dari Ftabel, dengan nilai $\mathrm{F}_{(0.05,14,23)}$ adalah 2,15. Dari Tabel 5 diketahui nilai $F_{\text {hitung }}$ sebesar 9,99 yang lebih besar dari $F_{(0.05,14,23)}=2,15$. Sehingga dapat diambil keputusan tolak $\mathrm{H}_{0}$, yang artinya adalah terdapat minimal satu parameter yang berpengaruh signifikan terhadap persentase peserta aktif KB suntik di Provinsi Jawa Timur, sehingga perlu dilakukan pengujian parsial/individu.

2. Pengujian parameter model secara parsial/individu

Uji individu ini dilakukan setelah diketahui bahwa terdapat minimal satu parameter yang berpengaruh signifikan terhadap persentase peserta aktf KB suntik di Provinsi Jawa Timur, yang didapatkan dari hasil pegujian parameter secara serentak. Berikut adalah hipotesis yang digunakan dan hasil yang didapatkan dari pengujian parameter secara individu.

Tabel 6.

Tabel ANOVA Pengujian Parameter Secara Individu

\begin{tabular}{ccccc}
\hline \hline \multirow{2}{*}{ Variabel } & $\begin{array}{c}\text { Parame } \\
\text { ter }\end{array}$ & Koefisien & P-value & Keputusan \\
\hline \multirow{2}{*}{$\mathrm{X}_{1}$} & $\beta_{1}$ & 0,49 & 0,024 & Tolak $\mathrm{H}_{0}$ \\
& $\beta_{2}$ & $-353,39$ & 0,391 & Gagal Tolak $\mathrm{H}_{0}$ \\
& $\beta_{3}$ & $-0,87$ & 0,049 & Tolak $\mathrm{H}_{0}$ \\
$\mathrm{X}_{2}$ & $\beta_{4}$ & 42,57 & 0,0000 & Tolak $\mathrm{H}_{0}$ \\
& $\beta_{5}$ & 51,01 & 0,0001 & Tolak $\mathrm{H}_{0}$ \\
& $\beta_{6}$ & 172,76 & 0,018 & Tolak $\mathrm{H}_{0}$ \\
& $\beta_{7}$ & $-3,73$ & 0,0001 & Tolak $\mathrm{H}_{0}$ \\
$\mathrm{X}_{3}$ & $\beta_{8}$ & 20,89 & 0,000 & Tolak $\mathrm{H}_{0}$ \\
& $\beta_{9}$ & $-19,69$ & 0,059 & Gagal Tolak $\mathrm{H}_{0}$ \\
& $\beta_{10}$ & 2,58 & 0,029 & Tolak $\mathrm{H}_{0}$ \\
& $\beta_{11}$ & $-0,37$ & 0,537 & Gagal Tolak $\mathrm{H}_{0}$ \\
& $\beta_{12}$ & 15,75 & 0,014 & Tolak $\mathrm{H}_{0}$ \\
$\mathrm{X}_{4}$ & $\beta_{13}$ & 15,52 & 0,112 & Gagal Tolak $\mathrm{H}_{0}$ \\
& $\beta_{14}$ & 5,81 & 0,0188 & Tolak $\mathrm{H}_{0}$ \\
\hline \hline
\end{tabular}

Tabel 6 menunjukkan hasil pengujian parameter model secara individu. Dapat diambil keputusan tolak $\mathrm{H}_{0}$ jika $p$ value kurang dari $\alpha=0,05$. Berdasarkan Tabel 6 dapat diketahui bahwa terdapat beberapa parameter yang memiliki $p$-value lebih besar dari $\alpha$, sehingga diambil keputusan gagal tolak $\mathrm{H}_{0}$ yang artinya parameter tersebut tidak berpengaruh signifikan terhadap model. Dari parameter yang dimiliki masing-masing variabel prediktor, empat variabel prediktor tersebut masing-masing terdapat parameter yang signifikan terhadap model. Sehingga dapat disimpulkan bahwa seluruh variabel prediktor berpengaruh signifikan terhadap model.

\section{F. Pengujian Asumsi Residual}

Model yang dihasilkan dengan menggunakan analisis regresi nonparametrik spline truncated harus memenuhi beberapa asumsi. Asumsi tersebut antara lain residual harus identik, independen, dan berdistribusi normal. Berikut adalah hasil pengujian asumsi residual dari model regresi nonparametrik spline truncated dengan kombinasi knot.

1. Pengujian asumsi residual identik

Metode yang digunakan dalam pengujian asumsi residual identik menggunakan uji glejser. Uji glejser dilakukan dengan meregresikan antara harga mutlak dari residual dengan variabel prediktor. Berikut adalah hasil pengujian yang didapatkan.

Tabel 7.

ANOVA Pengujian Asumsi Residual Identik

\begin{tabular}{cccccc}
\hline \hline Sumber & df & SS & MS & Fhit & P-value \\
\hline Regresi & 4 & 53,92 & 13,48 & 1,22 & 0,321 \\
Error & 33 & 364,89 & 11,06 & & \\
Total & 37 & 418,81 & & & \\
\hline \hline
\end{tabular}

Tabel 7 menunjukkan tabel ANOVA dari hasil pengujian asumsi identik menggunakan metode uji glejser. Didapatkan nilai $\mathrm{F}_{\text {hitung }}$ sebesar 1,22 dan $\mathrm{P}$-value sebesar 0,321. Tolak $\mathrm{H}_{0}$ jika $F_{\text {hitung }}$ lebih dari $F_{\text {tabel, dengan }} F_{\text {tabel }(0.05,4,33)}$ sebesar 2,15 dan jika Pvaluekurangdari $\alpha=0,05$.Sehinggadapatdiambilkeputusangag al tolak $\mathrm{H}_{0}$ karena $\mathrm{F}_{\text {hitung }}$ kurang dari $\mathrm{F}_{\text {tabel }}$ dan $\mathrm{P}$-value lebih dari $\alpha$. Dari keputusan tersebut dapat disimpulkan bahwa tidak terjadi heteroskedastisitas, yang menunjukkan bahwa residual telah memenuhi asumsiidentik.

2. Pemeriksaan dan pengujian asumsi residual independen

Metode yang digunakan untuk memeriksa asumsi residual independen adalah dengan melakukan pengujian Durbin-Watson. Berikut merupakan hasil pengujian DurbinWatson.

Tabel 8.

Hasil Uji Durbin-Watson

\begin{tabular}{cccc}
\hline \hline Nilai $\boldsymbol{d}$ & Nilai $d_{\boldsymbol{L}}$ & Nilai $d_{\boldsymbol{U}}$ & Nilai $4-d_{\boldsymbol{U}}$ \\
\hline 2,09661 & 1,2614 & 1,7223 & 2,2777 \\
\hline \hline
\end{tabular}

Dari hasil pengujian pada Tabel 8 diketahui bahwa nilai $d_{U}<d<4-d_{U}$ berarti hasil keputusan adalah gagal tolak $\mathrm{H}_{0}$ atau tidak terjadi autokorelasi.

3. Pengujian asumsi residual berdistribusi normal

Metode yang digunakan untuk pengujian distribusi normal adalah dengan menggunakan uji Kolmogorov Smirnov, serta dilakukan pemeriksaan secara visual dengan melihat Normal Probability Plot Residual. Berikut adalah hasil pengujian menggunakan uji Kolmogorov-Smirnov dan hasil pemeriksaan pola plot residual dengan menggunakan Normal Probability Plot.

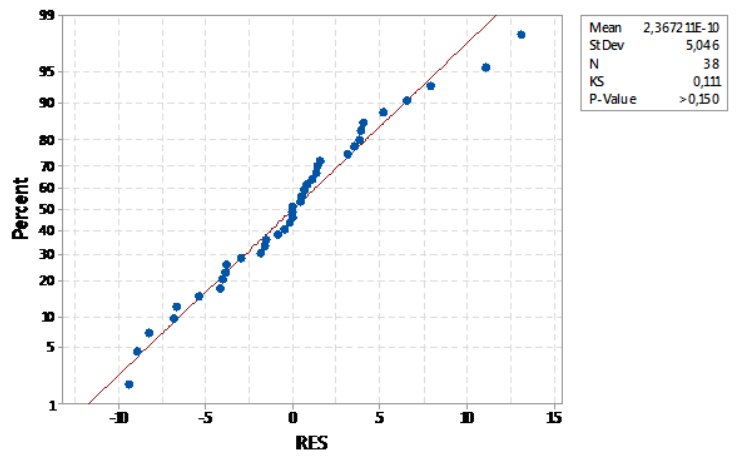

Gambar 2. Hasil Uji Distribusi Normal.

Gambar 2 menunjukkan hasil uji distribusi normal menggunakan uji Kolmogorov-Smirnov dan hasil pemeriksaan menggunakan residual normal probability plot residual, terlihat bahwa plot residual telah mengikuti garis lurus $45^{\circ}$, dan didapatkan nilai $\mathrm{P}$-value $>0,150$. Sehingga dapat disimpulkan bahwa gagal tolak $\mathrm{H}_{0}$ yang artinya residual telah memenuhi asumsi distribusi normal.

\section{G. Interpretasi Model Regresi}

Dari hasil analisis yang telah dilakukan sebelumnya, didapatkan model regresi nonparametrik spline truncated yang terbaik adalah dengan menggunakan kombinasi knot. Berikut adalah model terbaik dengan kombinasi knot yang telah didapatkan.

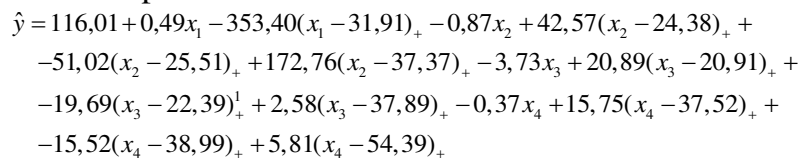

Model tersebut memiliki koefisien determinasi atau $\mathrm{R}^{2}$ 
sebesar 85,87 persen, artinya model tersebut mampu menjelaskan variabilitas dari variabel prediktor yang masuk ke dalam model sebesar 85,87 persen. Dari model tersebut dapat diinterpretasikan sebagai berikut.

1. Jika variabel $X_{2}, X_{3}$, dan $X_{4}$ dianggap konstan maka pengaruh persentase penduduk perempuan berstatus kawin usia 15 - 49 tahun dan menggunakan KB terhadap persentase peserta aktif $\mathrm{KB}$ suntik adalah sebagai berikut.

$$
\begin{aligned}
\hat{y} & =0,49 x_{1}-353,40\left(x_{1}-31,91\right)_{+}^{1} \\
& =\left\{\begin{array}{c}
0,491 x_{1}<31,91 \\
-352,91 x_{1}+11276,99 \geq 31,91
\end{array}\right.
\end{aligned}
$$

Dengan model tersebut untuk variabel $\mathrm{X}_{1}$, maka diketahuiwilayah yang termasuk dalam interval pertama adalah Kabupaten Madiun, Kabupaten Magetan, Kota Madiun, Kabupaten Ponorogo, Kota Kediri, Kota Surabaya, Kabupaten Ngawi, Kota Mojokerto, Kabupaten Banyuwangi, Kota Blitar, Kabupaten Sidoarjo, Kabupaten Blitar, Kabupaten Trenggalek, Kabupaten Tulungagung, Kabupaten Pacitan, Kota Pasuruan, Kota Malang, Kabupaten Lamongan, Kabupaten Lumajang, Kabupaten Bojonegoro, Kabupaten Nganjuk, Kabupaten Kediri, Kabupaten Jombang, Kabupaten Malang, Kabupaten Mojokerto, Kabupaten Situbondo, Kabupaten Sumenep, Kota Probolinggo, Kabupaten Jember, Kota Batu, Kabupaten Tuban, Kabupaten Gresik, Kabupaten Bangkalan, KabupatenPasuruan, Kabupaten Pamekasan dan Kabupaten Probolinggo. Pada interval tersebut apabila penduduk perempuan berstatus kawin usia 15-49 tahun dan menggunakan $\mathrm{KB}$ bertambah 1 persen maka persentase peserta aktif KB suntik akan bertambah sebesar 0,491 Berikut merupakan peta pembagian wilayah berdasarkan variabel $\mathrm{X}_{1}$

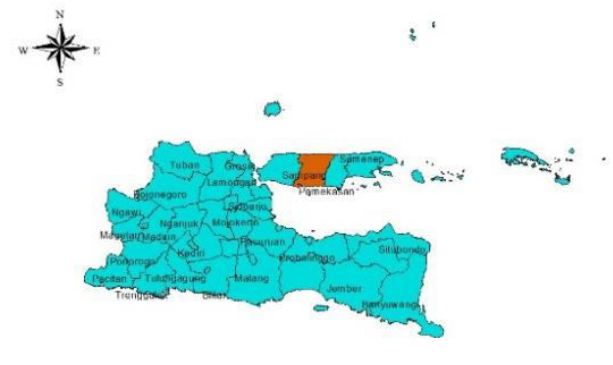

$$
\underset{\square}{\substack{\text { Interval } \\>31,91}}
$$

Gambar 3. Peta Provinsi Jawa Timur Berdasarkan Variabel $X_{1}$.

2. Jika variabel $X_{1}, X_{3}$, dan $X_{4}$ dianggap konstan maka pengaruh persentase penduduk perempuan usia $15-49$ tahun dengan jumlah anak lahir hidup lebih dari sama dengan 2 terhadap persentase peserta aktif $\mathrm{KB}$ suntik adalah sebagai berikut.

$$
\begin{aligned}
\hat{y} & =-0,87 x_{2}+42,57\left(x_{2}-24,38\right)_{+}^{1}-51,02\left(x_{2}-25,51\right)_{+}^{1}+172,76\left(x_{2}-37,37\right)_{+}^{1} \\
& =\left\{\begin{array}{c}
0,87 x_{2}, x_{2}<24,38 \\
43,44 x_{2}-103,87,24,38 \leq x_{2}<25,51 \\
-7,58 x_{2}+263,66,25,51 \leq x_{2}<37,37 \\
165,18 x_{2}+6192,38, x_{2} \geq 37,37
\end{array}\right.
\end{aligned}
$$

Dengan model tersebut untuk variabel $\mathrm{X}_{2}$, maka untuk wilayah-wilayah yang termasuk pada interval pertama apabila persentase perempuan usia 15 - 49 tahun dengan jumlah anak lahir hidup dua kurang dari 24,38 persen bertambah satu persen maka persentase peserta aktif KB suntik akan naik sebesar 0,87 persen. Jika persentase perempuan usia 15 - 49 tahun dengan jumlah anak lahir hidup lebih dari dua berada pada wilayah di interval kedua, yaitu di antara lebih dari atau sama dengan 24,38 persen hingga kurang dari 25,51 persen, bertambah satu persen maka persentase peserta aktif KB suntik akan naik sebesar 43,44 persen. Di interval terakhir, yaitu wilayah dengan perempuan usia 15 - 49 tahun dengan jumlah anak lahir hidup minimal dua lebih dari atau sama dengan 37,37 persen dan apabila pada interval tersebut bertambah satu persen maka persentase peserta aktif KB suntik bertambah 165,18 persen. Berikut merupakan peta pembagian daerah di Jawa Timur berdasarkan $\mathrm{X}_{2}$.

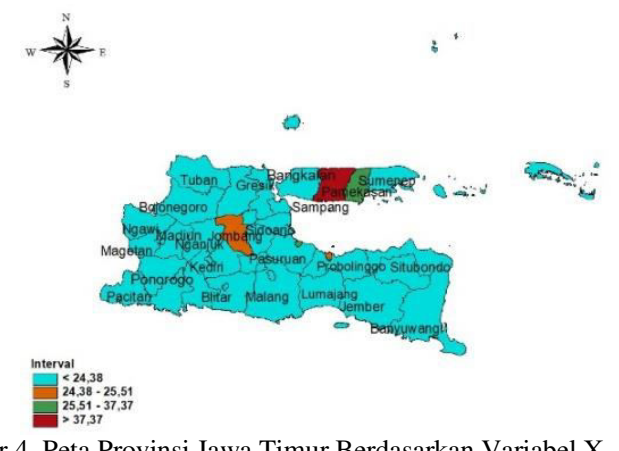

Gambar 4. Peta Provinsi Jawa Timur Berdasarkan Variabel $\mathrm{X}_{2}$.

3. Jika variabel $X_{1}, X_{2}$, dan $X_{4}$ dianggap konstan maka pengaruh persentase penduduk perempuan berstatus kawin usia $15-49$ tahun dengan pendidikan minimal SLTA/sederajat dan menggunakan alat KB terhadap persentase peserta aktif KB suntik adalah sebagai berikut. $\hat{y}=-3,73 x_{3}+20,89\left(x_{3}-20,91\right)_{+}^{1}-19,69\left(x_{3}-22,39\right)_{+}^{1}+2,58\left(x_{3}-37,89\right)_{+}^{1}$

$$
=\left\{\begin{array}{c}
-3,73 x_{3}, x_{3}<20,91 \\
17,16 x_{3}-436,81,20,91 \leq x_{3}<22,39 \\
-2,53 x_{3}+877,67,22,39 \leq x_{3}<37,89 \\
0,05 x_{3}+779,91, x_{3} \geq 37,89
\end{array}\right.
$$

Berdasarkan model dapat diinterpretasikan dari masingmasing interval. Persentase peserta aktif KB suntik yang berada di wilayah yang termasuk pada interval pertama akan mengalami penurunan sebanyak 3,73 persen apabila persentase perempuan berusia 15 - 49 tahun dengan pendidikan terakhir minimal SLTA/sederajat dan sedang menggunakan KB mengalami kenaikan sebesar satu persen. Pada interval kedua, yaitu wilayah yang memiliki persentase perempuan berusia 15 - 49 tahun dengan pendidikan minimal SLTA/sederajat dan sedang menggunakan alat KB diantara lebih dari atau sama dengan 20,91 persen hingga 22,39 persen, pada interval tersebut apabila bertambah satu persen maka persentase peserta aktif KB suntik akan naik sebesar 17,16 persen. Di interval keempat persentase peserta aktif KB suntik akan bertamabah 0,05 persen apabila interval persentase perempuan berusia 15 - 49 tahun dengan pendidikan minimal SLTA/sederajat naik satu persen dari 37,89 persen. Berikut merupakan peta daerah-daerah di Jawa Timur berdasarkan variabel $\mathrm{X}_{3}$.

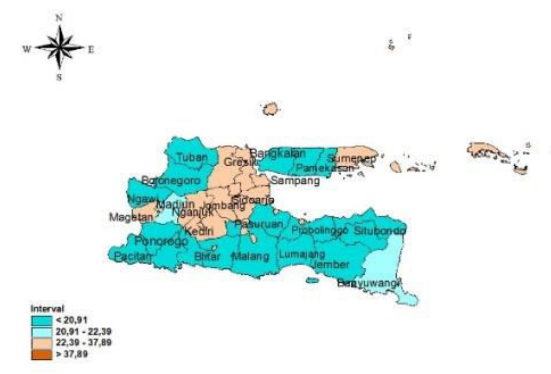

Gambar 5. Peta Provinsi Jawa Timur Berdasarkan Variabel $\mathrm{X}_{3}$. 
4. Jika variabel $X_{1}, X_{2}$, dan $X_{3}$ dianggap konstan maka pengaruh persentase penduduk perempuan berstatus kawin usia 15 - 49 tahun dengan usia kawin pertama lebih dari atau sama dengan 19 tahun terhadap persentase peserta aktif KB suntik adalah sebagai berikut.

$$
\begin{aligned}
\hat{y} & =-0,37 x_{4}+15,75\left(x_{4}-37,52\right)_{+}^{1}-15,52\left(x_{4}-38,99\right)_{+}^{1}+5,81\left(x_{4}-54,39\right)_{+}^{1} \\
& =\left\{\begin{array}{c}
-0,37 x_{4}, x_{4}<37,52 \\
15,38 x_{4}-590,94,37,52 \leq x_{4}<38,99 \\
-0,14 x_{4}+14,18,38,99 \leq x_{4}<54,39 \\
5,67 x_{4}+301,82, x_{4} \geq 54,39
\end{array}\right.
\end{aligned}
$$

Dari model tersebut dapat diinterpretasikan, pada interval 37,52 persen hingga 38,99 persen, jika persentase perempuan usia 15 - 49 tahun dengan usia kawin pertama lebih dari atau sama dengan 19 tahun naik sebesar satu persen maka persentase peserta aktif KB suntik akan naik sebesar 15,38 persen. Dan pada interval perempuan usia 15 - 49 tahun dengan usia kawin pertama lebih dari atau sama dengan 19 tahun lebih dari 54,39 persen, jika naik sebesar satu persen maka persentase peserta aktif $\mathrm{KB}$ suntik akan naik sebear 5,67 persen. Berikut merupakan peta daerahdaerah di Jawa Timur berdasarkan variabel $\mathrm{X}_{4}$.

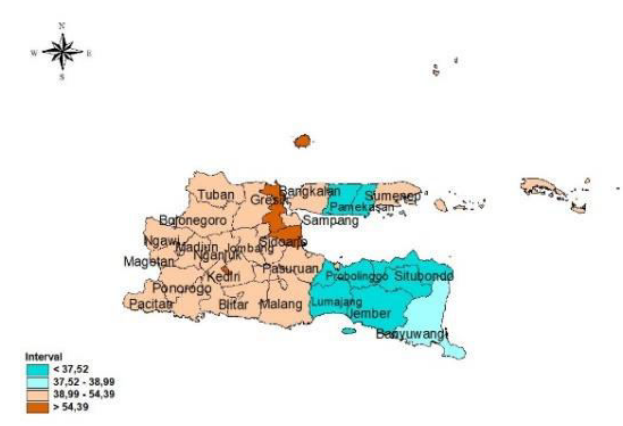

Gambar 6. Peta Provinsi Jawa Timur Berdasarkan Variabel $\mathrm{X}_{3}$.

\section{KESIMPULAN DAN SARAN}

\section{A. Kesimpulan}

Berdasarkan hasil analisis dan pembahasan dari penelitian ini dapat diambil kesimpulan sebagai berikut.

1. Di Provinsi Jawa Timur rata-rata persentase perempuan yang merupakan peserta aktif KB suntik adalah sebesar 55,92 persen. Persentase ini termasuk cukup tinggi karena apabila diinterpretasikan dari 100 orang perempuan di Jawa Timur, 56 orang perempuan diantaranya sedang menggunakan alat KB berupa suntik atau lebih dari separuh perempuan di Provinsi Jawa Timur merupakan peserta aktif KB suntik.

2. Dengan menggunakan metode GCV minimum diketahui model terbaik didadapatkan dari model kombinasi knot (1-3-3-3). Model tersebut memiliki koefisien determinasi atau $\mathrm{R}^{2}$ sebesar 85,87 persen, artinya model tersebut mampu menjelaskan variabilitas dari variabel prediktor yang masuk ke dalam model sebesar 85,87 persen. Serta keempat variabel prediktor dugaanberpengaruh signifikanterhadap persentase peserta aktif KB suntik.

B. Saran

Saran yang dapat diberikan dari hasil penelitian ini adalah peneliti sebaiknya turun secara langsung pada daerah-daerah tertentu apabila terdapat interpretasi yang tidak sesuai denganrasionalitas. Sebaiknya juga lebih teliti dalam mengolah data dan interpretasi sehingga hasil yang didapatkan lebih baik lagi dan dapat menjadi referensi untuk penelitian selanjutnya.

\section{DAFTAR PUSTAKA}

[1] BKKBN, "Laporan Hasil Pelayanan Alat Kontrasepsi," 2013

[2] Budijanto, "Determinan '4 Terlalu' Masalah Kesehatan Reproduksi Hubungannya dengan Penggunaan Alat KB Saat Ini di Indonesia," Bul. Jendela Data dan Inf. Kesehat., vol. 2, pp. 17-24, 2013.

[3] A. Saifuddin, "Buku Panduan Praktis Pelayanan Kontrasepsi," Jakarta, 2006.

[4] D. N.R and S. H., Analisis Regresi Terapan. Jakarta: Gramedia Pustaka Utama, 1992.

[5] A. Tripena and I. Budiantara, "Fourier Estimator in Nonparametric Regression," in International Conference on Natural and Applied Natural Science, 2006, pp. 2-4.

[6] A. P. Sugiantari and I. N. Budiantara, "Analisis Faktor-faktor yang Mempengaruhi Angka Harapan Hidup di Jawa Timur Menggunakan Regresi Semiparametrik Spline," J. Sains dan Seni ITS, vol. 2, no. 1, pp. D37-D41, 2013.

[7] I. N. Budiantara, "Penelitian Bidang Regresi Spline Menuju Terwujudnya Penelitian Statistika yang Mandiri dan Berkarakter," in Seminar Nasional FMIPA, 2011.

[8] W. Hardle, Applied Nonparametric Regression. New York: Cambridge University Prees, 1994.

[9] B. Lestari, I. N. Budiantara, S. Sunaryo, and M. Mashuri, "Spline Smoothing for Multiresponse Nonparametric Regresssion Model in Case of Heteroscedasiticity of Variace," J. Math. Stat., pp. 377-384, 2012.

[10] I. Wulandari and I. N. Budiantara, "Analisis Faktor-faktor yang Mempengaruhi Persentase Penduduk Miskin dan Pengeluaran Perkapita Makanan di Jawa Timur Menggunakan Regresi Nonparametrik Birespon Spline," J. Sains dan Seni, pp. D30D35, 2014.

[11] A. A. Fernandes, I. N. Budiantara, B. W. Otok, and Suhartono., "Spline Estimator for Bi-Response and Multi-Predictors Nonparametric Regression Model in Case of Longitudinal Data," J. Math. Stat., vol. 11, no. 2, pp. 61-69, 2015.

[12] I. Budiantara, "Estimator Spline Terbobot dalam Regresi Semiparametrik," Maj. Ilmu Pengetah. dan Teknol., vol. 10, pp. 103-109, 1999.

[13] N. Chamidah, I. N. Budiantara, S. Sunaryo, and I. Zain, "Disigning of Child Growth Based on Multirespon Loca Polynomial Modeling," J. Math. Stat., vol. 8, no. 3, pp. 342-347, 2012.

[14] I. Budiantara, "Metode Spline Multivariabel dalam Regresi Nonparametrik," in Makalah Seminar Nasional Matematika, 2014.

[15] I. Budiantara, "Regresi Nonparametrik Spline Truncated," ITS, Surabaya, 2017.

[16] S. F. Nisa' and I. Budiantara, "Analisis Survival dengan Pendekatan Multivariate Adaptive Regression SPline pada Kasus Demam Berdarah Dengue (DBD)," J. Sains dan Seni ITS, pp. D318-D323, 2012.

[17] A. A. Fernandes, I. N. Budiantara, B. W. Otok, and Suhartono. "Reproducing Kernel Hilbert Space for Penalized Regression Multi Predictors : Case in Longitudinal Data," Int. J. Math. Anal., vol. 8 , no. 40, pp. 1951-1961, 2014.

[18] R. L. Eubank, Nonparametric Regression and Spline Smoothing, Second Edition. New York: Taylor \& Francis, 1999.

[19] D. Gujarati, Basic Econometrics, 4th ed. New York: Mc Graw Hill Companies, 2004

[20] W. Daniel, Statistika Non Parametrik. Jakarta: Gramedia, 1989. 